\title{
A formação humana no contexto da consumação metafísica do sujeito: ética da potência de Agamben
}

\author{
The human formation in context of consummation metaphysics of subject: \\ ethics of power in Agamben
}

\section{La formación humana en el contexto de consumación metafísica del sujeto: la ética del poder de Agamben}

\begin{abstract}
ALEXANDRE SimÃo DE FREITAS* $\diamond$

RESUMO - A presente reflexão toma o chamado giro pós-teológico-político na filosofia contemporânea como ponto de partida para a tematização de alguns dilemas que atravessam os processos e as práticas que articulam a educação na atualidade. Para isso, evoca a figura do pobre como imagem (pesrsonagem, ou símbolo? pra não ficar tão repetitivo) excêntrica de nossa modernidade pedagógica. Essa figura é um intercessor privilegiado na ontologia da potência desdobrada pelo pensador italiano Giorgio Agamben. Tematiza-se, assim, em que medida sua ética da potência permite retomar os princípios que animam o debate sobre a formação humana.
\end{abstract}

Palavras-chave - Metafísica da subjetividade. Ética da potência. Teologia política.

\begin{abstract}
This reflection takes the so-called post-theological-political in contemporary philosophy as a turning point for the thematization of some dilemmas that cross processes and practices linking education today. To do so, he evokes the figure of the poor as eccentric figure of our pedagogical modernity. The intercessor of argumentation is the ontology of power deployed by the Italian thinker Giorgio Agamben, thematising is thus to what extent its ethical power lets you resume the principles that animate the debate on human formation.
\end{abstract}

Keywords - Metaphysics of subjectivity. Ethics of power. Political theology.

RESUMEN - Esta reflexión toma lo llamado giro pos-teológico-político en la filosofía contemporánea como un punto de inflexión para la tematización de algunos dilemas que atraviesan procesos y prácticas que se vinculen la educación actual. Para ello, evoca la figura del pobre como figura excéntrica de nuestra modernidad pedagógica. El intercesor de la argumentación es la ontología del poder desplegado por el pensador italiano Giorgio Agamben, reflejando pues en qué medida su ética del poder permite reanudar los principios que animan el debate sobre la formación humana.

Palabras clave - La metafísica de la subjetividad. La ética del poder. La teología política.

\footnotetext{
* Doutor em Sociologia pela Universidade Federal de Pernambuco (Recife, PE, Brasil) e professor na Universidade Federal de Pernambuco (Recife, PE, Brasil).E-mail:<alexshiva@uol.com.br>.
} 


\section{NOTAS INTRODUTÓRIAS}

Tornou-se banal afirmar que se vive uma época de mudança, ou, mais que isso, que se vive uma verdadeira mudança de época. Após a chamada era da secularização (TAYLOR, 2007), diferentes análises voltaram a matizar o mal-estar na cultura e as patologias sociais decorrentes do processo de modernização. Assim, admite-se que as mudanças que se vivencia estariam afetando o discernimento moral e o próprio ideal de pessoa que se aprendeu a cultivar ao longo da modernidade.

Como resultado, os efeitos profundos e acelerados das desregulações políticas, econômicas e morais de hoje provocariam sentimentos difusos de perplexidade e impotência. Nesse âmbito, a falta de sentido tornou-se, mais uma vez, uma questão central que seguiria o processo de desencantamento e desmagificação do mundo. Ao mesmo tempo em que expressaria a prevalência de um modelo de self entrincheirado (COSTA, 2010), indicando um quadro de motivos que estaria na origem das dificuldades que paralisam os processos que articulam as decisões morais.

Nos termos de Mustapha Chérif (2013, p. 12), a dessignificação do mundo reflete, mais amplamente, uma ruptura entre a responsabilidade e a liberdade, o que significa que os costumes ou as leis não seriam condições suficientes para assegurar a retidão do que se faz ou mesmo do que se tenciona fazer. Disso decorre a sensação de ruptura com um ethos culturalmente transmitido. $\mathrm{O}$ efeito dissonante seria uma espécie de conformismo generalizado expresso pelo individualismo e pela indiferença, configurando uma nova anatomia moral marcada pelo crepúsculo da ideia de dever.

O pano de fundo incontornável dessa situação é a consciência da particularidade das normas morais a partir da explosão da consciência da pluralidade e das diferenças. Tudo isso atravessado por uma crítica concreta aos sistemas de produção globalizados, à depredação dos ecossistemas, à pauperização mundial, enfim, ao sistema sociocultural como um todo. Esse horizonte pressionado pela ausência de sentido potencializa a "ditadura do mercado", fazendo com que "a capacidade de pensar, de pensar diferentemente" (CHÉRIF, 2013, p. 13) seja afetada e mesmo questionada.

Esse cenário, contudo, vem sendo interpretado de modos bem distintos. Por um lado, há uma abordagem cínica ou desesperada, segundo a qual todo projeto de futuro, nesse contexto, torna-se inviável. Nos termos de Jean-Luc Nancy, postula-se que estaria se vivendo na esfera da desolação (NANCY, 2005, p. 147-153).

Por outro lado, defende-se o chamado caminho da superação: aqui cada derrota levaria a um aprendizado e a um acúmulo de forças revolucionárias, de forma que o momento de maior derrota representaria também a maior oportunidade de reação. Zizek (2007) chama isso de “argumento de Hölderlin". E, finalmente, há uma terceira hipótese de leitura na qual a "ruína ética" é apreendida como uma oportunidade na fragilidade (DERRIDA, 2003, p. 13), ou seja, a própria experiência da "ruína ética" é percebida enquanto abertura para a criação singular de novos sentidos.

Nesse último âmbito, as ações humanas seriam necessariamente marcadas por uma insegurança ontológica estrutural e, portanto, seria preciso aprender a agir levando em conta essa situação que, longe de ser um convite ao niilismo, seria a condição para manifestar novos modelos compreensivos da ação humana. A partir dessa posição, toda forma de engajamento ético implicaria também o esforço de pensar contra si mesmo, revendo-se as consequências do que, em dado momento, aparece como claro.

Pode-se chamar esse esforço de "sensibilização à alteridade", a qual demanda a reativação de uma pedagogia portadora de sensibilidades renovadas para com o sofrimento alheio e para com as próprias fragilidades intrínsecas ao discurso e ao movimento do pensar. $\mathrm{O}$ problema é que esse esforço exige uma "démarche de tirar o fôlego" (COSTA, 2010, p. 23), pois visa a defender o universalismo ético em um quadro intelectual dominado pelo relativismo e pelo liberalismo multiculturalista.

Além disso, toda essa discussão guarda um enigma inexplorado pelas ciências humanas, em geral, e pela pedagogia, em particular: o fato de o pensamento moderno não ter rompido completamente com horizontes teológicos de justificação da ação, como, aliás, já haviam percebido Nietzsche, Weber e Foucault (BERTEN, 2011). Desse ponto de vista, por exemplo, não seria difícil remontar à teologia,buscando as principais concepções de natureza humana. A própria concepção moderna de subjetividade, com suas noções nucleares de autonomia e autenticidade, emerge vinculada aos exercícios espirituais de ascetismo com suas variadas formas de autoexame e conhecimento de si.

Assim, por vias curiosas, o pensamento contemporâneo tem reabilitado por meio de exegeses específicas "o valor ético de religiões comumente vistas como eurocêntricas ou comprometidas com uma longa história de opressão de povos, culturas e indivíduos" (COSTA, 2010, p. 23). Independentemente da linguagem mobilizada e de suas possíveis deficiências ou limitações, transparece aqui um pensamento ético que se apresenta como forma sui generis de ensejar uma abertura radical à alteridade no interior do que tem sido denominado como uma delicada virada pós-teológico-política.

Essa virada não pretende em absoluto o fim das correspondências teológico-políticas, mas o anúncio de 
um desarmamento improvável de sua marca soberana. Em outras palavras, busca "conservar uma atitude, uma dignidade, uma ética, mesmo se nada garantir a felicidade" (CHÈRIF, 2013, p. 16), visando tão somente a uma escuta do outro que permita reconhecer que existem outras maneiras de apreender o mundo. Nesses termos, trata-se de apreender o que são a humanidade, o humano, a existência, ultrapassando simultaneamente as "formas pervertidas do humanismo clássico" e as versões fechadas dos "tradicionalismos religiosos" (p. 20), ou seja, tratase de pensar a questão da secularização e as pretensões equívocas do poder teocrático de governar.

Por isso, talvez, não seja de todo sem sentido, e essa é a aposta central desse texto, pensar a formação humana sob os traços tênues dessa virada. Vale lembrar que toda e qualquer reflexão sobre a formação humana tem de passar pela ética e pela consciência da existência do outro. Nessa perspectiva, é possível tomar o giro pós-teológico-político da filosofia contemporânea como ponto de partida, não necessariamente de chegada, para uma reflexão ampliada sobre alguns dilemas que atravessam os processos e as práticas que articulam a educação na atualidade.

Logo, não se trata de assumir o teológico-político como um dado irredutível da reflexão pedagógica, mas de abrir uma hipótese inicial de leitura, que pode e deve ser tomada em toda sua problematicidade e equivocidade pelos pensadores da área. A intenção consiste em refletir em que medida os princípios éticos que animam o debate sobre a formação humana podem ser revisitados e enriquecidos pela virada pós-teológico-política de autores como Giorgio Agamben, Jacques Derrida, Slavoj Zizek, Antonio Negri, Alan Badiou e Jean Luc Nancy. Contudo, o intercessor privilegiado aqui é a ontologia da potência desdobrada pelo pensador italiano Giorgio Agamben.

A escolha justifica-se na medida em que Agamben tem movido suas pesquisas no âmbito da filosofia política, explorando intencionalmente a relação entre teologia e política, o que permite tematizar em que medida sua ética da potência contribui para repensar os princípios que animam o debate sobre a formação humana.

\section{A REFUNDAÇÃo DA ÉTICA, O CANTO MESSIÂNICO E AS PREMISSAS DO TEOLÓGICO-POLÍTICO}

É inegável que conceitos políticos como os de soberania popular, utopia social, direitos humanos, estado de exceção, representação, entre outros, podem encontrar equivalentes teológicos mais antigos.

No entanto, essa precedência da teologia, na filosofia política, incorre em erro ao negligenciar as fortes relações de poder que sempre permearam o próprio discurso teológico (AGAMBEN, 2007), bem como elidir o fato da teologia como apologia institucional. Por essas razões, as premissas teológico-políticas devem ser mais especificadas para evitar a essencialização das categorias mobilizadas.

Isso é ainda mais importante na medida em que, neste momento, a própria teologia está reconfigurando a composição das ciências humanas; e disciplinas como ciência política, literatura, história e psicanálise sentem o impacto desse retorno (DAVIS, 2014, p. 07). Os autores que têm se debruçado sobre esse fenômeno indicam duas razões para o entendimento ampliado desse retorno do teológico-político em nossas reflexões: o colapso do comunismo e a expansão mundial do capitalismo.

\begin{abstract}
Em resposta ao advento desse niilismo capitalista, o pensamento - o ato de pensar - foi obrigado a encontrar um novo caminho adiante. Ele teve de apelar a uma tradição que poderia resistir à hegemonia do capitalismo e seu pressuposto - a vontade de poder individual. Os pensadores da resistência à depredação capitalista não podiam mais recorrer apenas à tradição marxista-humanista, ainda mais enquanto a história do marxismo realmente existente se desdobrava diante da força destruidora do capitalismo. Esse caminho foi a abertura para o teológico (DAVIS, 2014, p. 07).
\end{abstract}

Entretanto, esse diagnóstico não elide a ambivalência do teológico-político enquanto tentativa de reconciliar transcendência e materialismo militante. Pois, se, por um lado, admite-se que os conflitos materiais da existência não podem ser amortizados em prol de uma retirada para a transcendência, por outro, há que se superar os preconceitos gerais quanto à transcendência apreendida como uma espécie de ópio, uma forma de alienação mistificadora. Ora é justamente a transcendência que há muito assombra o pensamento crítico (HABERMAS, 2013), uma vez que do ponto de vista de uma esfera pública democrática apenas aquelas proposições religiosas que abdicassem da imposição violenta das suas verdades de fé poderiam receber o predicado de razoáveis.

Ao mesmo tempo, a reflexão filosófica em torno das questões ontológicas quase sempre defendeu a subsunção do devir à transcendência. A exceção, por sua vez, pode ser encontrada na deriva estoica que elevou o devir como instância primeira, atravessando todos os níveis da existência. Com isso, nos sistemas de pensamento contemporâneos atravessados por um furor antimetafísico, uma filosofia em devir inevitavelmente contribuiria para expulsar a transcendência das suas ontologias. Como se explica, então, que nessa inesperada virada pós-teológicopolítica o devir contribua também para alimentar novas formas de transcendência?

Deleuze (2002), por exemplo, em seu último texto, considera que uma transcendência poderia emergir de 
uma imanência, ou seja, poderia resultar de um devir sem diques, monstruoso. Nos seus termos, diferentemente das transcendências conhecidas (o mundo das ideias, o Deus escolástico, o imperativo categórico), essa transcendência selvagem não se oporia à imanência, mas a perfuraria e a faria transbordar, como "uma ferida [que] se encarna ou se atualiza em um estado de coisas e em um vivido" (p. 17). Sabe-se que essa ferida seria um puro virtual sobre o plano de imanência transportado em uma vida. Assim, embora "minha ferida" exista "antes de mim", a transcendência da ferida nunca é tomada como "atualidade superior".

Mas, independentemente do estatuto efetivo desse novo "campo transcendental" que se apresenta como uma pura corrente de consciência a-subjetiva, quer dizer, sem fazer apelo a um eu (DELEUZE, 2002, p. 10), a possibilidade mesma da sua postulação obriga a um exercício de pensamento que evoca a todo tempo um não saber, tendo em vista que promove e alimenta uma conceituação cuja única função é abandonar conceitos que se desfazem para tentar aceitar (e não conceber) a possibilidade do inconcebível ${ }^{1}$. Assim, é no interior mesmo dessa aporia que a rejeição secular à transcendência tem sido reconsiderada, reconhecendo-se a necessidade de desdobrar uma ontologia capaz de interpelar as trajetórias do poder constitutivo da vida.

Logo não é casual que as premissas do pensamento pós-teológico-político contemporâneo travem um combate em torno do problema do ato ou do gesto revolucionário em relação aos controles normalizadores do biopoder (ESPOSITO, 2013, p. 285-286). Mas essa discussão só faz sentido desde que se leve em consideração a perspectiva de suas relações básicas, ou seja, a relação entre mito e razão na modernidade. Pois o giro pós-teológico-político configura-se também como uma tentativa de equalizar, mais uma vez, crença e fé, luta política e Estado secular.

Trata-se da busca de um ponto de equilíbrio tenso na medida em que "cada um dos lados [racionalista e fideísta] não é só incapaz de falar com o outro, [e] não precisa fazê-lo para subsistir" (DAVIS, 2014, p. 13), ou seja, cada lado não precisa arriscar sua própria posição. Uma situação que acaba por fazer do debate entre o teológico e o político algo de bastante improvável, embora essa mesma improbabilidade seja justamente o que desafia a totalidade do presente político.

Isso significa que a inércia graças à qual as injustiças do passado se perpetuam só poderia ser quebrada pela irrupção de algo radicalmente novo; é esse surgimento do imprevisível na tessitura mesma da história, na esteira da herança de autores como Walter Benjamin, o que fornece concretude ética à tarefa messiânica. O canto messiânico permitiria pensar o não sintetizável sobre a diferença, ao contrário de toda uma tradição filosófica na qual o Mesmo absorveria o Outro em sua efetividade ${ }^{2}$.
As ressonâncias desse canto fazem então confluir sentidos renovados de justiça e cuidado como forma de guardar a potência da alteridade. O messianismo é o evento que guarda a abertura "ao imprevisível advento do Outro" (COSTA, 2010, p. 266). Esse Outro não apreendido a partir das idas e vindas do Ser, mas como homens e mulheres singulares, cujas vidas e obras concretas, como as de Antígona ou de Abraão, cairiam sobre nós como um choque, chamando nossa atenção para a existência de um rosto singular: o rosto do órfão, da viúva e do estrangeiro ou ainda dos excluídos, dos imigrantes ilegais, dos sem-teto, dos desvalidos de toda ordem.

A sugestão provocadora para a reflexão filosófica e por que também não dizer pedagógica que decorre dessas proposições consiste em afirmar de modo incisivo o fato de que a força da justiça seria a fraqueza do amor pelos sem-poder.

\section{A VIDA HUMANA DO POBRE ENTRE O BIOPODER E A ALTERIDADE}

Na obra publicada em 2007, Il regno e la gloria, Giorgio Agamben inicia afirmando que sua investigação se propõe a mostrar que dois grandes paradigmas modernos, conexos e antinômicos ao mesmo tempo, o da filosofia política da soberania e o da economia política do governo, derivam-se da teologia cristã. Para o pensador italiano, as teorias da soberania modernas decorrem de uma teologia política que secularizou o poder soberano de Deus e o transferiu para a figura do Estado, embora mantendo intacto o paradigma da transcendência, o que torna a soberania moderna uma forma de teologia política. Desse modo, Agamben desdobra a tese de que a noção moderna de economia derivaria, na verdade, da chamada oikonima teológica ${ }^{3}$.

Desse último paradigma se articula a biopolítica moderna, bem como as formas de administração e governo da vida que proliferam por todos os âmbitos institucionais (ESPOSITO, 2013, p. 287). A genealogia da inclusão da vida humana na oikonomia teológica faz retroagir a origem da política ocidental à noção de economia da salvação. Nessa noção se encontram implicadas a vida divina e a história da humanidade.

Mais uma vez, vale ressaltar que também nesse aspecto o estoicismo ocupa um lugar estrangeiro aos nossos sistemas de pensamento na medida em que pretende preservar o livre arbítrio das pessoas junto com a vontade divina que rege o mundo. Para o estoicismo, a noção de providência se identificava com a necessidade da natureza, enquanto, para o cristianismo, a economia da providência deve respeitar a liberdade humana e articulála com o plano divino da salvação. Nesse caso, a teologia econômica aponta uma solução dos problemas históricos 
que não se resolvem com meras opções e decisões políticas, senão através de técnicas administrativas e formas governamentais.

Agamben (2007, p. 37) conclui incisivamente que a oikonomia teológica seria a matriz da economia moderna, já que em ambas se desenvolvem conhecimentos e métodos de governo da vida humana 4 . Para ele, a oikonomia teológica colocou como questão central a necessidade de compatibilizar o plano da salvação de Deus sobre o mundo com o respeito à liberdade humana e a sua natureza de ser livre. Sugestivamente, a economia moderna também portaria a mesma questão central no seu discurso.

A pergunta sobre como governar a população respeitando a natureza e os seus desejos torna-se objeto de uma nova área do saber: a economia política. Mas esta, afirma Agamben, mantém o marco teórico da teologia econômica do governo mudando Deus ora pelo Estado, ora pelo mercado. Assim, a questão da oikonomia teológica se transfere para a economia política que agora se pergunta como governar as pessoas. Com a ressalva de que como governar as pessoas implica questionar suas aspirações, medos, ansiedades, gostos e esperanças. Em outras palavras, governar para a economia política significa antes de tudo governar a liberdade dos outros, ou seja, administrar a sua vontade e dirigi-la para metas preestabelecidas.

Com isso, a noção de providência divina é reapropriada e deslocada na forma de construção das técnicas de governo que compatibilizam as tendências naturais das populações com as metas desejadas pelas instituições. O resultado é produção em grande escala de táticas utilitárias de fabricação de desejos, controle das condutas, normalização dos comportamentos e regulamentação dos processos de subjetivação.

A economia torna-se governo da vida. Essa afirmação, no entanto, deixa em aberto a pergunta pelo tipo de vida em jogo; qual é a vida humana que deve ser governada? Para responder a essa questão, Agamben (2007, p. 53) retoma ao seu modo as distinções que os gregos fizeram sobre os dois conceitos de vida: zoe e bios. Distinção que permite diferenciar a vida que plantas, animais e seres humanos têm em comum (a zoe) e a vida que pode-se construir para além da mera vida imposta pela natureza (a bios). Essa última, sendo apreendida como a vida propriamente humana, ou seja, a vida que é construída justamente pela ética e pela política.

Agamben (2007, p. 81) insiste, contudo, em lembrar que o objeto principal da economia teológica também é a vida humana. O problema é que o termo utilizado para a vida na economia teológica não era nem zoe, nem bios, mas zoe aionos (vida eterna). E o uso dessa noção não teria nada de inocente. O filósofo não hesita em classificá-la como uma vida a ser governada (nesse caso, pela vontade divina), cujo paradigma se associa ao modelo hierárquico da oikos. Entretanto, a zoe aionos era também o paradigma da teologia messiânica que propunha a ruptura histórica, ou seja, tomava como referência a possibilidade mesma de irrupção divina na história ${ }^{5}$.

Nos termos de Agamben, isso significa que um conflito teológico mais profundo acerca da vida humana se transferiu para os paradigmas políticos e econômicos modernos; se a economia teológica é o paradigma da economia política, a teologia messiânico-profética pode então ser considerada o paradigma dos movimentos de resistência. A teologia messiânico-profética estaria na raiz dos movimentos de conta-conduta (contraconduta?) pastoral para usar uma linguagem foucaultiana. Desse modo, enquanto a economia política se direciona a administrar a vida humana como recurso natural, os movimentos sociais reivindicam a potencialidade política da ruptura em nome da vida.

Para os dispositivos econômicos, a vida humana se torna um objeto útil a ser administrado segundo a sua natureza. Porém essa mesma vida também se manifesta como alteridade irredutível à objetivação nas reivindicações sociais ${ }^{6}$. Nessa segunda compreensão, os movimentos e as lutas sociais apresentariam um leque ampliado de opções sobre o modo de entender a vida humana, desde a alternativa messiânica de puxar o freio do modelo predador da vida, como propunha Benjamin, à proposta de revolução armada em autores como Sorel ou Fanon. Para todos eles, cada instante seria uma porta por onde pode entrar o Messias; cada instante estaria assim aberto à possibilidade mesma do novo, do inédito, da ruptura ou simplesmente da revolução.

A partir disso, o problema das escolhas do sujeito é trazido à tona, e com ele uma nova compreensão da questão da subjetividade em sua dimensão ética. Fala-se de um sujeito comprometido com uma ética por vir; um sujeito movido e atravessado por atos e atitudes inspirados no cuidado de si e dos outros.

\section{A CONSUMAÇÃO METAFÍSICA DO SUJEITO NA ÉTICA DA POTÊNCIA ${ }^{7}$}

Chegamos, assim, ao ponto nodal dessa insólita reflexão. O caminho trilhado na esteira da virada pósteológico-política permite repensar a questão do sujeito e da educação que lhe é correlata pela delimitação de outra experiência de pensamento. Nos termos de Nunes (2014), trata-se de pensar o sujeito da educação através da chamada figura do pobre. Segundo esse autor, o pobre se constitui em figura excêntrica da modernidade pedagógica na medida em que representa um mero objeto das redes de poder-saber que articulam as práticas educativas nas sociedades. 
O pobre, como se sabe, é a figura paradigmática das formas de assujeitamento econômico, político, social e cultural, encarnando o lugar de múltiplas desigualdades que fazem dele o sujeito da falta. No máximo, ele aparece como alvo de uma sociologia crítica da pobreza, que ora o apreende por meio de práticas higienistas, ora por meio de políticas públicas direcionadas a promover os seus direitos (negados) de cidadania. Mas, no âmbito das reflexões inspiradas na virada pós-teológico-política, o pobre também se constitui em uma figura singular da própria condição humana.

O pobre encarnaria uma espécie de linha de fuga, alimentando os processos de resistência aos controles biopolíticos. Em um de seus trabalhos mais recentes, Altíssima pobreza, Agamben vislumbra na pobreza a enunciação de uma experiência do humano como potência pura de ser e de não ser. Pobres e pobreza são por ele interrogados "numa direção contrária às investigações cuja regra geral é descrever, informar ou denunciar as faces do seu infortúnio" (CERQUEIRA, 2010, p. 21) . $^{8}$

Nos termos foucaultianos, a disciplinarização dos pobres, no alvorecer da modernidade, esvaziou a pobreza de todo estatuto ontológico privilegiado, aparecendo como simples carência econômica; a pobreza deixa de ser uma figura da transcendência, caindo na órbita do mundo social. Como resultado, a figura do pobre passou a atrair para si uma concepção moral que, ao invés de santificá-la, a torna alvo de condenação.

No limite, ela se transformou em figura da abjeção. Admite-se, nesse caso, que os pobres contribuem para esfacelar as fronteiras sociais, desdobrando um cenário complexo de confinamento, uma vez que eles abririam uma ferida nos interstícios da sociedade. Sua mera presença produziria constrangimento: sua existência poderia desvelar não tanto as disfunções da cidade, mas seu funcionamento efetivo. Com isso, os pobres passaram a serem investigados como elementos de uma população flutuante identificada por meio dos critérios de renda, acesso aos bens e serviços e/ou oportunidades de acesso à cultura; medidos e classificados.

Os pobres atualizam a cisão entre os integrados e os outsiders. Mas sua desqualificação indica mais que uma exclusão econômica pura; está associada a um complexo jogo de (des)valorização dos modos de ser, de se relacionar, enfim, de viver a própria vida. Mais ainda: para Agamben (2002, p. 16), haveria uma relação entre o modo de pensar uma política de contenção dos pobres e o esforço de definição do próprio homem na medida em que a politização na vida nua é "a tarefa metafísica por excelência, na qual se decide da humanidade do vivente homem". Ou seja, na fratura biopolítica que busca cercear ou simplesmente eliminar a pobreza e os pobres, consuma-se a metafísica da subjetividade, pois é esta que permite traçar uma espécie de limiar entre a vida protegida e aquela que deve ser exposta e abandonada à morte; vida nua ou vida sacra, essa vida (do) pobre constitui o conteúdo primeiro do poder soberano.

Por isso, a generalização do caráter sacer da vida humana acaba por converter o pobre em um problema pedagógico de primeira ordem. Se outrora coube ao hospital geral encerrar os vagabundos, os mendigos, as prostitutas, a nova sensibilidade gerada pelas práticas biopolíticas reconstruiu a figura do pobre como uma questão a ser resolvida em termos de escolarização obrigatória. A pobreza como uma espécie de mal a ser evitado exige do campo pedagógico toda uma semântica moralista em torno do "dever ser" dos pobres. Aporética, a experiência formativa dos pobres tem como maior infortúnio sua própria condição, uma vez que a pobreza é o que, no limite, dificultaria a própria educação; embora a saída da pobreza só seja alterada qualitativamente pela educação mesma. Desse modo, o pobre ocupa

um lugar de subtração e exibindo sempre alguma forma de apagamento de si. Por isso, ao conjunto da plebe nomeia-se 'povo', título que prima pela mesma indiferenciação atribuída às 'classes populares'. Ambas são formas que sugerem uma adequação [moral] da política à pobreza (CERQUEIRA, 2010, p. 22-23).

As clivagens provocadas pela relação educaçãopobreza revelam que os pobres estão no centro de uma problematização que não se reduz a questões meramente sociais. O pobre aparece como uma figura-limite entre o homem e o não homem, entre a vida que merece ser vivida e aquela que pode ser descartada. Logo, a pedagogia da pobreza desvela a pobreza da pedagogia atrelada à máquina antropo-pedagógica moderna com seu processo infinito de in/exclusão. A modernidade pedagógica articula a figura do pobre como o símbolo extremo do outro humano. Isso revela que, ao tematizar a condição ontológica da pobreza, toda questão do homem e, portanto, toda tarefa pedagógica de humanização é pensada de outros modos.

Sabe-se, em Agamben, que homem não define uma substância, mas funciona como uma máquina que busca produzir o reconhecimento do humano através do afastamento do não humano. Nessa perspectiva, na figura do pobre se encontra desvelada a captura da potência pela máquina antropológica moderna ${ }^{9}$. Nas palavras de Michael Haar (1990, p. 96): "O que a metafísica esquece, de modo crescente, é a pobreza do homem". Todo homem é um homem despossuído, desapropriado de uma essência fixa e regular. Apenas o homem pode não ser, o que há de específico no homem é a possibilidade de (não-)ser, de ser sua própria impotência, o fato de ele poder ser e poder-não-ser. 
Todo homemé, portanto, essencial e fundamentalmente pobre. A questão da pobreza emergindo aqui, enquanto um traço de toda vida humana em meio à sua própria facticidade. Esse traço leva a crer que as determinações sociais, econômicas, etc., não esgotam o ser mesmo do humano. Daí por que a pobreza envolve uma noção originária de privação. Esta consiste, para o homem, em pôr seu próprio ser em jogo.

A pobreza ontologicamente reconfigurada faz do homem um habitante do possível. Pensada nesses termos, a experiência da pobreza inverte toda a lógica da necessidade que legitima a figura do pobre como desvalido e carente. Prostrado em sua pobreza, todo ser humano habitaria o reino da pura potência. Por essa razão, o homem não deve ser pensado a partir de suas obras, mas enquanto ser que "se expõe constitutivamente à possibilidade da própria falta e inoperância" (AGAMBEN, 2008, p. 385), o que permite deparar com uma visão radical do humano e da sua formação.

\section{O QUE PODE A EDUCAÇÃO, OU MELHOR, PODE A EDUCAÇÃO SUA PRÓPRIA IMPOTÊNCIA?}

No início dessa reflexão, admite-se o diagnóstico de que o tempo hoje é atravessado pela sensação difusa de que se está de "mãos atadas", ou seja, de que não se pode fazer nada para mudar as próprias condições de vida. Ao longo desse percurso analítico, procurou-se ressaltar que a falta de sentido pode decorrer também do sequestro das potências pelos biopoderes. Por isso, paradoxalmente, esses mesmos biopoderes, ao separar os homens do que eles podem (não) fazer, atira-os no irresponsável "pode-se tudo", admitindo como possibilidade real atrocidades cada vez maiores contra determinados grupos sociais e disseminando a violência nas relações:

\begin{abstract}
Separado da sua impotência, privado da experiência do que pode não fazer, o homem de hoje crê-se capaz de tudo e repete seu jovial 'não há problema' e o seu irresponsável 'pode fazer-se', precisamente quando deveria antes dar-se conta de ser entregue numa medida inaudita a forças e processos sobre os quais perdeu qualquer controle. Tornou-se cego não às suas capacidades, não ao que pode fazer, mas ao que não pode ou pode não fazer (AGAMBEN, 2010, p. 58).
\end{abstract}

Nessa leitura, toda potência, todo poder fazer, é inseparável da impotência, do poder-não fazer: "O homem é, por conseguinte, o ser vivo que, existindo sob o modo da potência, pode tanto uma coisa como o seu contrário, trate-se de fazer ou de não fazer" (AGAMBEN, 2010, p. 58). Há então que reter essa capacidade de se manter em relação com a sua possibilidade de não fazer, o que define o estatuto próprio da sua ação.

Isto não significa, todavia, que o homem não seja nem deva ser alguma coisa, que ele seja simplesmente entregue ao nada e possa, portanto, decidir ser ou não ser à sua vontade, atribuir a si ou não atribuir este ou aquele destino (niilismo e decisionismo encontram-se neste ponto). Há, de facto, algo que o homem é e tem de ser, mas este algo não é uma essência, não é propriamente uma coisa: é o simples facto da sua própria existência como possibilidade ou potência. Mas é justamente por isso que tudo se complica, que a ética se torna efectiva (AGAMBEN, 2010, p. 38. Itálicos do autor).

Com esse argumento, Agamben delineia uma curiosa ética da potência. Uma ética que não visa a nomear uma nova vocação histórico-espiritual, nem postular o exercício de uma vontade soberana a ser realizada,e sim manter uma "relação justa com uma ignorância [...] Ou, para usarmos um vocabulário caído em desuso, que aquilo que nos é mais íntimo e melhor alimenta tenha (corrigir) a forma não da ciência e do dogma, mas da graça e do testemunho" (AGAMBEN, 2010, p. 132).

Nessas circunstâncias, o encontro com a própria potência pode ser algo terrível. Essa experiência podelevar a uma situação de pânico ao desvelar que algo se excede sob todos os aspectos, pois uma vez que o homem não dispõe de si como uma propriedade, a vida humana seria uma vida sem o próprio; uma vida através da qual aquilo que se é se manifesta apenas como pura possibilidade. Do que decorre a tarefa da educação que vem, ou seja, de uma formação humana inspirada na ética da potência: liberar o homem de toda a propriedade que o fixe, uma vez que a vida humana conserva a possibilidade de exceder suas formas.

Os comportamentos e as formas do viver humano não são prescritos em nenhum caso por uma vocação biológica específica nem impostos por uma ou outra necessidade; mas, ainda que sejam habituais, repetidos e socialmente obrigatórios, conservam em todo momento o caráter de uma possibilidade, quer dizer, põem sempre em jogo o viver mesmo (AGAMBEN, 2001, p. 14).

O sujeito metafísico é aqui deposto: que uma potência possa (não) ser, por sua vez, possuída significa a impossibilidade de um sujeito no sentido moderno, quer dizer, de uma consciência autorreflexiva como centro de imputação de faculdades e hábitos. A própria liberdade não pode ser pensada como uma propriedade do sujeito, passando igualmente por uma dessubjetivação. O essencial, portanto, de uma ética da potência é a 
possibilidade de o humano se colocar no umbral entre subjetivação e dessubjetivação. A ética da potência pensa o humano com outras cifras, uma vez que a inteligência, a racionalidade, a sensibilidade não são concebidas como predicados ônticos.

O sujeito deixa de ser apreendido como uma substância proprietária de atributos e faculdades, sendo percebido como uma espécie de privação sentida/sofrida desses atributos. Nessa ótica, a formação humana é o que permite abrir, a cada vez, o espaço em que aqueles atributos não cessam de (des)aparecer. A formação humana torna-se "o lugar possível, mas vazio, de uma ética, de uma forma-devida" (AGAMBEN, 2007, p. 60). Além disso, é movida, na ética da potência, pela capacidade de recusa a todos os mitos (des)humanos do progresso a qualquer custo, antepondo a esses mitos os sonhos de um mundo outro da/na educação para não deixá-la cair no vazio estéril e desolador das teorias que afirmam a circularidade do mesmo.

Assim, a formação humana abriria espaço para que circulasse a paixão de entrever outros modos de ser, nos quais ser ético corresponde à experiência daprópria impotência, diferenciando nessa experiência a identidade estatutária e o esforço de permanecer si mesmo. Figura frágil, o humano decorrente da ética da potência delineada por Agamben é por isso testemunha de outro estilo de transmissão. Ali, onde o educador podia descansar sobre a base que conferia a autoridade de sua disciplina ou de sua expertise, o gesto da formação humana imanente à ética da potência consiste apenas em responder/atestar, no âmbito davida de educadores/formadores, a urgência do que significa hoje viver uma experiência de formação. Isto é, exercer uma pedagogia que se realiza no risco da ausência de normatividades apreendidas em sentido absoluto. Nesse caso, a lição provocadora da ética da potência: a formação humana progride ou retroage com aqueles que a vivem.

\section{REFERÊNCIAS}

AGAMBEN, Giorgio. Altissima povertá: regole monastiche e forma di vita. Milano: Neri Pozza Editore, 2011.

AGAMBEN, Giorgio. Il regno e la gloria: per una genealogia teologica dell'economia e del governo. Milão: Neri Pozza, 2007.

AGAMBEN, Giorgio. Homo sacer: o poder soberano e a vida nua. Belo Horizonte: Editora UFMG, 2002.

AGAMBEN, Giorgio. Medios sin fin: notas sobre la política. Valencia: Pre-Textos, 2001.

AGAMBEN, Giorgio. Nudez. Lisboa: Relógio D’Água Editores, 2010.

BERTEN, André. Modernidade e desencantamento Nietzsche, Weber e Foucault. São Paulo, Editora Saraiva, 2011.
CERQUEIRA, Monique Borba. Pobres, resistência e criação: personagens no encontro da arte com a vida. São Paulo: Cortez, 2010.

CHÈRIF, Mustapha. O Islã e o Ocidente. Encontro com Jacques Derrida. Belo Horizonte: Editora UFMG, 2013.

COSTA, Jurandir Freire. O ponto de vista do outro. Rio de Janeiro: Garamond, 2010.

DAVIS, Creston. Sábado santo ou domingo da ressurreição? Preparando um debate improvável. In: ZIZEK, Slavoj; MILBANK, John. A monstruosidade de Cristo. São Paulo: Três Estrelas, 2014.

DELEUZE, Gilles. A imanência: uma vida. Revista Educação e Realidade, v. 27, n. 2, p. 10-18, 2002.

DERRIDA, Jacques. Foi et savoir. Paris: Flammarion, 1996.

HABERMAS, Jürgen. Fé e saber. São Paulo: Editora Unesp, 2013.

NANCY, Jean Luc. La communauté affrontée. Paris: Galilée, 2001.

NANCY, Jean Luc. La déclosion: déconstruction du christianisme, I. Paris: Galilée, 2005.

NEGRI, Antonio; HARDT, Michael. Commonwealth - el proyecto de una revolución del común. Madrid: Akal Ediciones, 2011.

NUNES, Cleiton de Barros. Educar na periferia de si mesmo: um estudo da noção de formação humana como potência dos pobres. 2014. 99 f. Dissertação (Mestrado em Educação) Centro de Educação, Universidade Federal de Pernambuco, Recife, 2014.

PIERRON, Jean-Philippe. Transmissão: uma filosofia do testemunho. São Paulo: Edições Loyola, 2010.

SAFATLE, Vladimir. O dever e seus impasses. São Paulo: Martins Fontes, 2013.

TAYLOR, Charles. A secular age. Cambridge, Massachusetts and London: The Belknap Press of Harvard University Press, 2007.

ZIZEK, Slavoj. The ongoing "soft revolution". Critical Inquiry, v. 30, n. 2, p. 292-323, 2004. http://dx.doi.org/ $10.1086 / 421126$.

\section{NOTAS}

1 Embora também se insista no fato de que essa articulação não visa uma saída do pensamento ou da racionalidade, mas um convite a, de fato, não pensar contra o inconcebível, nem apesar dele, mas com ele, aceitando sua possibilidade paradoxal e aporética (Cf. PIERRON, 2010).

2 O messianismo daria a ver, portanto, o Outro como o que não pode ser representável, o que não implica desconhecer o papel mediador dos códigos jurídicos e sociais por meio dos quais conhecemos ou experimentamos a falha e a abertura por onde emerge o que é inclassificável no ser humano.

3 Sabemos que, de alguma maneira, essa questão já tinha sido exposta pelo controvertido filósofo do direito Carl Schmitt ao afirmar, em 1922, que todos os conceitos decisivos da moderna doutrina do Estado são conceitos teológicos secularizados. Para Agamben (2007, p. 11), entretanto, uma genealogia teológica da economia amplia a abrangência da influência teológica para além do mero direito público da soberania. Essa genealogia envolveria a própria noção de vida humana e sua reprodução social.

4 O termo grego oikonomia tinha o sentido de governar a casa, entendendo o governo como administração hierárquica da vida de todos os integrantes da grande oikos grega ou domus romana. Já Aristóteles diferencia entre a 
arte de governar e administrar a oikos (oikonomia) e a arte da cidadania na polis (política). Na oikonomia não haveria decisão livre das pessoas, senão administração inteligente das vontades. $\mathrm{Na}$ ágora da polis deveria existir livre decisão dos sujeitos para construir o destino coletivo.

5 Por exemplo, no livro do Apocalipse, que é o livro por excelência da teologia messiânica cristã, aqueles que sobreviverem à grande perseguição serão levados até as fontes da vida (Apc, 7,17). No julgamento final prevalecerá a justiça dos justos, e estes terão seus nomes inscritos no "livro da vida" (Apc. 20,12). Esta metáfora da vida e dos nomes dos justos, na teologia messiânica, mantém uma tensão de contraste com a vida governada da teologia econômica (Cf. AGAMBEN, 2007, p. 89).

6 Pode-se dizer então que a zoe aionos da teologia apocalíptica se deslocou para as lutas sociais na forma de diversas categorias como vidas infames ou a vida dos mulçumanos.

7 A filosofia moderna do sujeito emergiu como um questionamento endereçado à metafísica antiga e medieval, embora para alguns pensadores essa crítica tenha se realizado em bases igualmente metafísicas. Por isso, enfatiza-se que o processo de legitimação epistêmica do sujeito moderno estaria subsumindo o fato de que o sujeito, ele mesmo, não se configura como um dado evidente.

8 Na mesma direção, Guillaume Le Blanc (2013) propôs que a História da Loucura na Idade Clássica, o primeiro livro de Michel Foucault, poderia ser lido como uma nova história da pobreza. Para Le Blanc (2013, p. 173), "loucos e pobres não cessaram de se olhar em um jogo de espelhos, de serem considerados como sujeitos das margens que uma longínqua semelhança acabava sempre por reinscrever em um espaço comum". Para ele, recuperar uma história da pobreza não é uma mera "curiosidade epistemológica".

9 Todo ser humano guardaria uma abertura à indigência, essa abertura cuidadosa que a experiência da facticidade traz como seu correlato para usar os termos heideggerianos (Cf. HAAR, 1990).

Artigo recebido em maio 2014.

Aprovado em junho 2015. 